\title{
Penggunaan Media Realita untuk Meningkatkan Hasil Belajar Siswa dalam Pembelajaran Matematika Kelas 1 SDN 005 Sunhai Alah
}

\author{
Ismearti \\ Guru Sekolah Dasar Negeri 005 Sunbai Alab Kecamatan Hulu Kuantan Kabupaten \\ Kuantan Singingi \\ e-mail: ismeartispd@gmail.com
}

\begin{abstract}
ABSTRAK. This study aims to increase mathematics learning outcomes by using reality media for grade 1 students of SDN 005 Sunhai Alah, Kecamatan Hulu Kuantan in 2018/2019. Research is a class action research with three cycles, each cycle consisting of planning, implementation, evolution and reflection. Data collection techniques and tools in this study used descriptive analysis techniques for data that contained student work documents, a list of grades and an observation sheet. The results show what is meant by learning outcomes using reality media. Before the action, only $38 \%$ of students met the minimum completeness criteria. In cycle I Is an increase in student learning outcomes that is $53 \%$ of students reach the minimum completeness criteria. Furthermore, the second cycle of student learning outcomes increased to reach $74 \%$ of students achieving the minimum completeness criteria. Then cycle III $100 \%$ of students reach the minimum completeness criteria. Can be used to prove the use of reality media to improve student learning outcomes in mathematics learning at grade 1 SDN 005 Sunhai Alah, Kecamatan Hulu Kuantan..
\end{abstract}

Kata kunci: Media Realita, Hasil Belajar.

\section{PENDAHULUAN}

Matematika merupakansalah satu ilmu dasar yang harus dikuasai oleh siswa karena tidak dapat dipisahkan dari kehidupan manusia sehari-hari. Sejarah menunjukkan bahwa matematika dibutuhkan oleh manusia. Sungguh tidak bisa dibayangkan, bagaimana keadaan dunia ini sekarang seandainya tidak ada matematika. Manusia tidak akan pernah bisa mendengarkan radio, melihat televisi, menaiki kereta api, mobil atau pesawat terbang bahkan tidak bisa berkomunikasi melalui telepon atau handphone. Dunia akan semakin kacau seandainya manusia tidak bisa berhitung secara sederhana, tidak bisa memahami ruang di mana dia tinggal, tidak bisa memahami harga suatu barang di pasar, dan sebagainya. Apa yang terjadi seandainya orang di Salatiga mengatakan $7+5=12$, sedangkan orang di Jakarta berpendapat $7+5=75$, atau kejadian-kejadian yang lain.

Ilustrasi di atas menunjukkan bahwa mata pelajaran matematika perlu diberikan kepada anak sejak usia sekolah dasar. Tujuannya adalah untuk membekali siswa dalam 
meningkatkan kemampuan berpikir logis, analitis, sistematis, kritis, kreatif serta kemampuan bekerjasama yang baik, yang nantinya dapat digunakan dalam mengelola dan memanfaatkan informasi untuk bertahan hidup pada keadaan yang selalu berubah, tidak pasti dan kompetitif pada era globalisasi sekarang ini.

Menurut Kline (1973), matematika bukanlah bagian tersendiri dari suatu ilmu pengetahuan tetapi kedudukannya lebih kepada melayani manusia untuk menyelesaikan masalah sosial, ekonomi dan ilmu alam, tidak hanya sekedar sebagai bahasa matematika saja tetapi juga sebagai cara berpikir logis.

Johnson dan Rising (1972) mengatakan bahwa matematika adalah pola berpikir, pola organisasi dan juga pembuktian secara logika. Matematika menggunakan definisi istilah dengan hati-hati, akurat dan jelas. Satu halkeuntungan terpenting dari belajar matematika adalah kemampuan berpikir analisis dan terstruktur.

Salah satu karakteristik matematika adalah mempunyai objek yang bersifat abstrak. Sifat abstrak inilah yang membuat banyak siswa mengalami kesulitan dalam belajar matematika. Oleh karena itu, hendaknya guru mampu menyajikan suatu pembelajaran matematika sekonkrit mungkin agar siswa lebih memahami materi yang disajikan.

Dalam pembelajaran matematika, khususnya di kelas I SD Negeri 005 Sungai Alah Kecamatan Hulu Kuantan, tentang nilai tempatmasih ada gejala-gejala dalam kegiatan belajar mengajar yang disebut dengan gejala problematis yaitu kurangnya minat siswa terhadap pembelajaran matematika, khususnya dalam penyampaian materi ajar. Oleh karena itu, guru perlu melakulan inovasi pembelajaran, khususnya dalam penyampaian materi ajar yaitu dengan menggunakan metode pembelajaran yang menarik perhatian siswa.

\section{METODOLOGI}

Penelitian ini merupakan Penelitian Tindakan Kelas. Penelitian ini dilaksanakan pada semester ganjil tahun pelajaran 2018/2019. Penelitian ini dilakukan di kelas I SD Negeri 005 Sungai Alah Kecamatan Hulu Kuantan Singingi. Subjek dalam penelitian ini adalah 10 siswa perempuan dan 3 siswa laki-laki. Sedangkan objek dalam penelitian adalah Metode diskusi, demontrasi. 


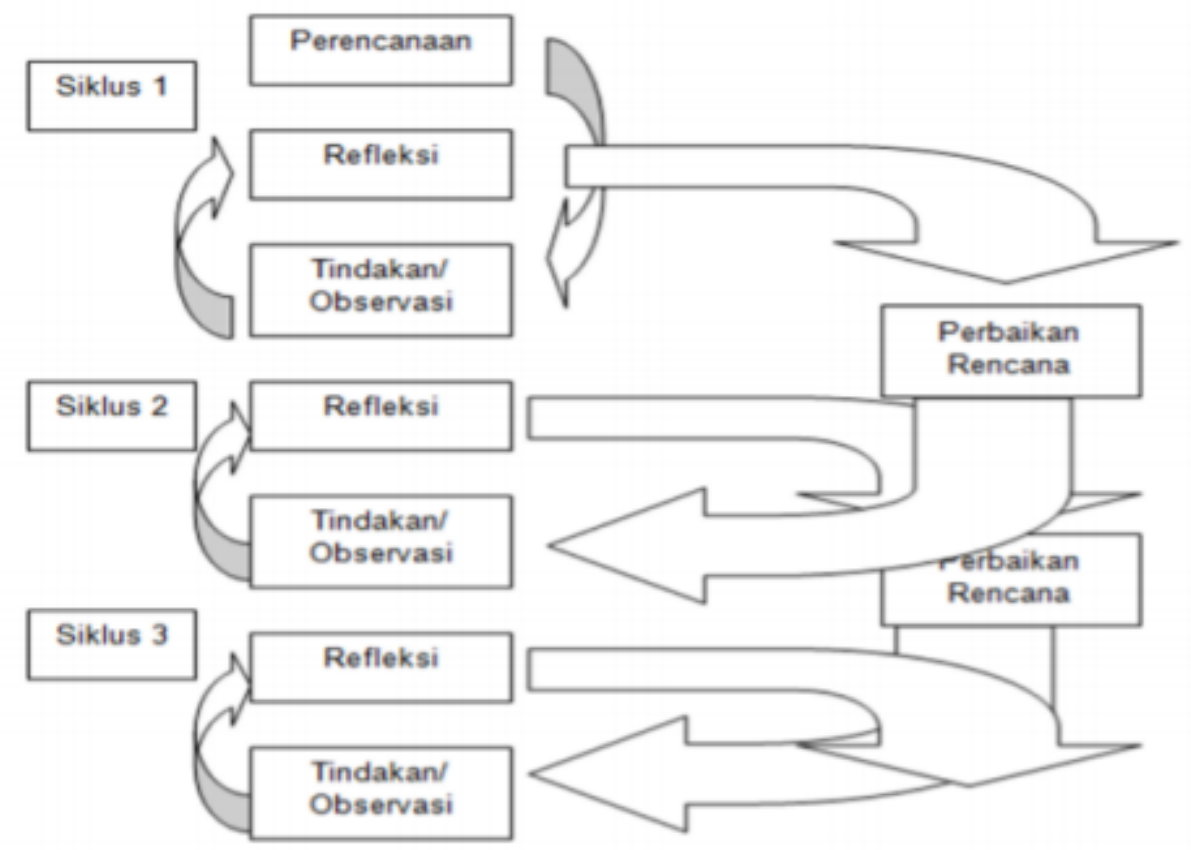

Populasi dalam penelitian ini adalah seluruh siswa kelas I SD Negeri 005 Sungai Alah Kecamatan Hulu Kuantan Singingi. Teknik pengambilan sampel yang digunakan adalah Random Sampling. Sedangkan Teknis analisis data yang digunakan adalah (1) Instrumen yang digunakan lembar observasi. Ini digunakan untuk pengamatan saat proses pembelajaran (2) Instrumen pengumpulan data tentang hasil belajar siswa dengan menggunakan lembar evaluasi siswa (3) Lembar soal tes dan lembar kerja siswa sudah tercantum dalam RPP.

\section{HASIL DAN PEMBAHASAN}

\section{Hasil Penelitian}

Hasil atau Temuan yang diperoleh pada setiap akhir pembelajaran siklus I, II, dan III, selalu diadakan tes evaluasi dan pengamatan.Hasil tersebut akan disajikan dalam bentuk tabel yang memuat isi keseluruhan hasil atau temuan yang diperoleh selama melaksanakan penelitian. Hasil tersebut diperoleh dari catatan-catatan peneliti sendiri dan catatan-catatan supervisor.

\section{Tabel 1. Frekuensi}

\begin{tabular}{lllllll}
$\begin{array}{c}\text { Rentang } \\
\text { Nilai }\end{array}$ & $\begin{array}{c}\text { Frekuensi } \\
\text { Siklus I }\end{array}$ & $\begin{array}{c}\text { Prosentase } \\
\text { Siklus I }\end{array}$ & $\begin{array}{c}\text { Frekuensi } \\
\text { Siklus II }\end{array}$ & $\begin{array}{c}\text { Prosentase } \\
\text { Siklus II }\end{array}$ & $\begin{array}{c}\text { Frekuensi } \\
\text { Siklus III }\end{array}$ & $\begin{array}{c}\text { Prosentase } \\
\text { Siklus III }\end{array}$ \\
\hline $0-29$ & 1 & $2,70 \%$ & 0 & $0 \%$ & 0 & $0 \%$ \\
$30-59$ & 5 & $38,50 \%$ & 2 & $16,60 \%$ & 1 & $2,70 \%$ \\
$60-79$ & 7 & $58,80 \%$ & 10 & $69,40 \%$ & 5 & $38,30 \%$ \\
$80-100$ & 0 & $0 \%$ & 1 & $2,70 \%$ & 7 & $58,80 \%$ \\
\hline Jumlah & $\mathbf{1 3}$ & $\mathbf{1 0 0} \%$ & $\mathbf{1 3}$ & $\mathbf{1 0 0} \%$ & $\mathbf{1 3}$ & $\mathbf{1 0 0 \%}$ \\
\hline
\end{tabular}


Tabel 2. Hasil Belajar Siswa pada Mata Pelajaran Matematika

\begin{tabular}{|c|c|c|c|}
\hline NAMA SISWA & SIKLUS I & SIKLUS II & SIKLUS III \\
\hline AK & 50 & 60 & 60 \\
\hline En & 60 & 70 & 80 \\
\hline IDG & 50 & 66 & 70 \\
\hline MAR & 70 & 70 & 80 \\
\hline MRNS & 70 & 80 & 90 \\
\hline MP & 60 & 70 & 85 \\
\hline MA & 70 & 75 & 85 \\
\hline WA & 35 & 45 & 70 \\
\hline YD & 45 & 60 & 66 \\
\hline $\mathrm{AP}$ & 75 & 60 & 70 \\
\hline AKA & 30 & 66 & 95 \\
\hline APR & 75 & 70 & 80 \\
\hline BMA & 20 & 40 & 55 \\
\hline Jumlah & 1780 & 2325 & 2662 \\
\hline Rata-rata & 49.44 & 64,58 & 73,94 \\
\hline
\end{tabular}

Peningkatan hasil belajar siswa pada mata pelajaran Matematika melalui metode diskusi,demonstrasi dan penggunaan media relia pada siswa kelas I semester I SD Negeri 005 Sungai Alah Kecamatan Hulu Kuantan dapat dilihat dari hasil ulangan yang dilaksanakan dalam pembelajaran pada pra siklus sampai siklus III dapat disajikan pada tabel berikut ini.

\section{Pembahasan}

\section{Siklus I}

Hasil belajar siswa data dari tes akhir pada siklus I menunjukkan bahwa siswa memperoleh nilai 60 ke atas pada mata pelajaran Matematika sebanyak 7 siswa dari 13 orang siswa atau 38,8 \%. Ini berarti kriteria pada siklus I ini pada pelajaran Matematika belum memenuhi target bahkan masih jauh dari yang diharapkan, yaitu siswa yang mendapat nilai 60 keatas sebesar $85 \%$ atau lebih.

Refleksi Pada akhir siklus I diperoleh hasil belajar siswa belum memenuhi kriteria keberhasilan yang ditetapkan. Berdasarkan hasil pengamatan guru dan supervisor 2 terdapat beberapa hal yang perlu diperhatikan dari keseluruhan yang diamati yaitu : (a) Guru belum optimal dalam membangkitkan minat siswa untuk belajar; (b) guru kurang tegas dalam pembagian kelompok belajar; (c) guru kurang memperhatikan pemahaman pada siswa tentang pentingnya kerja sama dalam kelompok untuk menyelesaikan suatu masalah; (d) guru belum optimal dalam menanamkan prinsip cara mengkonstruksi sebuah pemahaman pada anak.

Pembelajaran yang kurang memuaskan hasilnya itu juga disebabkan oleh siswa itu sendiri, yaitu : (1) Sebagian siswa belum memahami hakikat dari pembelajaran yang diikuti; (2) Dalam kegiatan pembelajaran, siswa banyak yang ribut dan tidak memperhatikan penjelasan guru; (3) Siswa kurang aktif dalam diskusi kelompok, tanya jawab, maupun kegiatan lain yang seharusnya dilakukan siswa.

\section{Siklus II}

Hasil belajar siswa data dari tes akhir pada siklus II menunjukkan bahwa siswa memperoleh nilai 60 ke atas pada mata pelajaran matematika sebanyak 10 siswa dari 13 
siswa atau 69,4\%. Ini berarti kriteria pada siklus II ini pada mata pelajaran matematika sudah banyak mengalami kemajuan dan hampir memenuhi target walaupun masih harus dan bisa ditingkatkan lagi sesuai dengan yang diharapkan, yaitu siswa yang mendapat nilai 60 keatas sebesar $85 \%$ atau lebih.

Refleksi Pada akhir siklus II diperoleh hasil belajar siswa belum memenuhi kriteria keberhasilan yang ditetapkan. Berdasarkan hasil pengamatan guru teman sejawat terdapat beberapa hal yang perlu diperhatikan dari keseluruhan yang diamati yaitu : (a) Guru perlu mengoptimalkan dalam memotivasi dan membangun minat siswa terhadap pelajaran matematika; (b) Guru mempertegas dalam pembagian tugas dalam kelompok belajar; (c) Guru kurang memperhatikan pemahaman pada siswa tentang pentingnya kerja sama dalam kelompok untuk menyelesaikan suatu masalah; (d) Guru belum optimal dalam menanamkan prinsip cara mengkonstruksi sebuah pemahaman pada anak, yaitu dengan mengaitkan peristiwa dan pengalaman-pengalaman yang dimiliki dalam kehidupan seharihari.

Pembelajaran yang kurang memuaskan hasilnya itu juga disebabkan oleh siswa itu sendiri, yaitu : (a) Sebagian siswa belum memahami hakikat dan strategi dari pembelajaran yang diikuti; (b) Dalam kegiatan pembelajaran, siswa banyak yang ribut dan tidak memperhatikan penjelasan guru; (c) Siswa kurang aktif dalam diskusi kelompok, tanya jawab, maupun kegiatan lain yang seharusnya dilakukan siswa.

\section{Siklus III}

Hasil Belajar Siswa Data dari tes akhir pada siklus III menunjukkan bahwa siswa memperoleh nilai 80 ke atas pada mata pelajaran matematika sebanyak 7 siswa dari 13 orang siswa atau 80,5\%. Ini berarti kriteria pada siklus III ini baik mata pelajaran matematika sudah banyak mengalami kemajuan dan sudah memenuhi target yang diharapkan, yaitu siswa yang mendapat nilai 60 keatas sebesar $85 \%$ atau lebih, dan hasil yang diperolehnya telah sesuai dengan target yang diharapkan.

Refleksi Pada akhir siklus III diperoleh hasil belajar siswa sudah memenuhi kriteria keberhasilan (KKM) yang ditetapkan. Berdasarkan hasil pengamatan guru teman sejawat terdapat beberapa hal yang perlu diperhatikan yaitu : Pembelajaran matematika dengan metode diskusi, demonstrasi dan penggunaan media relia pada siklus III sudah lebih baik dari siklus II, dan terjadi peningkatan hasil belajar siswa yakni sudah memenuhi apa yang diharapkan, karena terbukti hasil yang dicapai siswa pada mata pelajaran matematika dengan nilai lebih dari 60 sebanyak 13 siswa dari jumlah siswa keseluruhan yaitu 13 anak atau mencapai 92,59\%. Hal ini menunjukkan bahwa peranan guru dalam proses pembelajaran bukan hanya sebagai pengajar, tetapi lebih ditekankan sebagai fasilitator. Guru memfasilitasi siswa untuk berhasil dengan memberikan motivasi, dorongan dan pendampingan dalam kegiatan pembelajaran.

\section{KESIMPULAN DAN SARAN}

\section{Kesimpulan}

Penelitian Tindakan Kelas dilaksanakan di kelas I SD Negeri 005 Sungai Alah Kecamatan Hulu Kuantan, menggunakan media realia dengan metode diskusi dan demonstrasi. Penelitian ini dilakukan dalam 3 siklus. Setelah dianalisis antara siklus I $(38,8 \%)$, siklus II $(69,4)$ dan siklus III $(80,5 \%)$. Hal ini berarti ada peningkatan minat siswa 
terhadap mata pelajaran matematika pada materi perkalian. Peningkatan ini berdampak positif terhadap hasil belajar yakni semakin tinggi minat siswa terhadap pembelajaran matematika, semakin tinggi pula hasil belajar yang mereka capai untuk meraih prestasi. Maka peran guru menjadi sangat penting yaitu sebagai motivator dan fasilitator. Hal ini ditunjukkan hasil belajar siswa pada penelitian tindakan kelas.

\section{Saran}

Sehubungan dengan penelitian yang telah dilakukan, peneliti memberikan saran yang berkaitan dengan usaha meningkatan minat belajar siswa dalam pembelajaran matematika khususnya tentang perkalian, sebaiknya menggunakan media realia. Hendaknya guru selalu dapat mengembangkan metode pembelajaran yang menarik dan kreatif yang banyak melibatkan siswa sebagai upaya pengekspresian dari diri siswa, dan seyogyanya guru lebih dapat mamainkan peran guru sebagai motivator dan fasilitator.

\section{REFERENSI}

Agus N. Cahyo. (2013). Panduan Aplikasi Teori-Teori Belajar Mengajar Teraktual dan Terpopuler. Jogjakarta: DIVA Press.

Ahmad Susanto. (2013). Teori Belajar dan Pembelajaran di Sekolah Dasar. Jakarta: Kencana Prenada Media Group.

Hamzah B uno. (2011). Belajar degan Pendekatan PAIKEM (Pembelajarn Aktif Inovatif Lingkungan Kreatif, Efektif, dan Menarik. Jakarta: Bumi Aksara.

Melly Andriani dan Mimi Hariyani. (2013). Pembelajaran Matematika. Pekanbaru: Benteng Media.

Muhabibin Syah. (2008). Psikologi Belajar. Jakarta: PT Raja Grafindo.

Slameto. (2010). Belajar dan Faktor-faktor yang Mempengaruhinya. Jakarta: Rineka Cipta.

Sugiyono. (2009). Metode Penelitian Pendidikan Kuantitatif Kualitatif R\&D. Bandung: Alfabetta.

Sunyo Adi Purnomo dan Ranni Novianty. (2013). Games for Fun Learning and Teaching. Bandung: Yrama Widya.

Wardhani,I. G. A. K \& Wihardit, K. (2010). Penelitian Tindakan kelas.Jakarta: Universitas Terbuka. Jakarta

Muhsetyo, Gatot dkk. (2011). Pemelajaran Matematika SD. Jakarta: Universitas Terbuka

Slameto.( 1995). Belajar dan Faktor- Faktor Yang Mempengaruhi. Jakarta: Rineka Cipta. 